\title{
RAMP1 Gene
}

National Cancer Institute

\section{Source}

National Cancer Institute. RAMP1 Gene. NCI Thesaurus. Code C127136.

This gene is involved in the localization of calcitonin gene-related peptide type 1 receptor. 